\title{
The UK Modern Slavery Act 2015 Three Years On
}

Virginia Mantouvalou *

\begin{abstract}
This article provides a critical assessment of the UK Modern Slavery Act 2015 (MSA) three years after its enactment. It puts forward the following claims: first, that while criminalisation of individuals who engage in severe labour exploitation is welcome, the legislation has failed to increase prosecutions and provide adequate remedies to victims; second, that heavy reliance on criminal law for the regulation of severe labour exploitation is insufficient, because the broader political and legislative context suggests that there is no political will to address structural factors, including legal structures, that create vulnerability to exploitation; and third, that the MSA is too weak in tackling modern slavery by businesses in their supply chains, as existing evidence from business responses to the MSA indicates. The article concludes that despite the passing of the Act, there is much scope for improvement in measures for eliminating labour exploitation, even with regard to its most severe forms.
\end{abstract}

Key words: modern slavery, servitude, forced labour, exploitation, criminalisation, victims.

\section{Introduction}

In 2017, two brothers were convicted for arranging the travel for labour exploitation of men from Poland. ${ }^{1}$ The men were recruited to work for a Sports Direct warehouse in the UK. The brothers had employed someone in Poland to identify vulnerable people, over whom they would be able to exercise control. In the UK, the victims' passports were held, they were isolated, and kept in appalling living conditions. Victims said that they were treated 'like a piece of rubbish' and that the brothers 'destroyed their lives'. 2 The brothers were sentenced to six years in prison for modern slavery offences. Judge Stephen Coupland said, during sentencing, that this was a 'planned and systematic' instance of human trafficking. Albeit by no means an isolated incident, this case exemplifies the extremity of ill-treatment that workers can suffer.

The Modern Slavery Act 2015 (MSA) was enacted in order to tackle situations such as the above. At the time of its enactment, the then Home Secretary, Theresa May, described it as a 'historic milestone' that 'sends the strongest possible signal to

\footnotetext{
* Professor of Human Rights and Labour Law, UCL, Faculty of Laws. I am grateful to Alan Bogg, Hugh Collins, Jennifer Collins, Mark Dsouza, George Letsas, Robert McCorquodale, Kate Roberts, and two anonymous referees for comments on a draft of this piece. Many thanks are also due to Joe Atkinson and Natalie Sedacca for excellent research assistance.

${ }^{1}$ This is a Crown Court decision and is unreported. See 'Sports Direct Modern Slavery Brothers Jailed' (BBC News, 23 January 2017) at http://www.bbc.com/news/uk-england-derbyshire-38721900; see also 'Recycling Slavery Gang Jailed for 32 Years' (Resource, 1 June 2017) at http://resource.co/article/recycling-slavery-gang-jailed-32-years-11885. Unless otherwise stated, all URLs were last accessed 19 March 2018.

${ }^{2}$ BBC News, above n 1.
} 
criminals that if you are involved in this vile trade you will be arrested, you will be prosecuted and you will be locked up. And it says to victims, you are not alone - we are here to help you'. ${ }^{3}$ The MSA was also characterised as 'world-leading'. A year later, after she became Prime Minister, May wrote an article in The Telegraph reaffirming the Government's commitment to defeating modern slavery. ${ }^{4}$ She said: 'These crimes must be stopped and the victims of modern slavery must go free. This is the great human rights issue of our time, and as Prime Minister I am determined that we will make it a national and international mission to rid our world of this barbaric evil'. Over two years since its enactment, in December 2017, the National Audit Office published a highly critical report on the UK response to modern slavery. ${ }^{5}$ The Report emphasized that the Home Office does not have a complete picture of the crime of modern slavery, the victims and the perpetrators, or an effective system to track any progress. Examining the Government's Modern Slavery Strategy of 2014, it found that there is lack of clarity when it comes to accountability, that the identification, support, and protection of victims is inadequate, and that there have been few prosecutions.

This article critically assesses the MSA three years after it was passed, drawing on theoretical literature, legal analysis, and existing empirical findings. ${ }^{6}$ It puts forward the following claims: first, that while criminalisation of individuals who engage in severe labour exploitation is welcome, the legislation has failed to increase prosecutions and provide adequate remedies to victims; second, that heavy reliance on criminal law for the regulation of severe labour exploitation is insufficient, because the broader political and legislative context suggests that there is no political will to address structural factors, including legal structures, that create vulnerability to exploitation; and third, that the MSA is too weak in eliminating modern slavery by businesses in their supply chains, and that existing evidence from business responses to the MSA indicates this. The article concludes that despite the passing of the Act, there is much scope for improvement in tackling labour exploitation, even in its most severe forms, both at the level of identifying and prosecuting individuals, and at the level of addressing structural factors that create vulnerability to exploitation.

The structure of the article is as follows: Part 2 briefly presents how the MSA became part of the UK policy agenda, explores its main components, and examines the meaning of slavery, servitude, forced and compulsory labour. A stated purpose of the Act was to increase prosecutions, but this has not been fulfilled, as this section shows. Part 3 turns to the National Referral Mechanism (NRM), a system through which victims of modern slavery are identified, and explores its shortcomings. Part 4 discusses the broader question of whether the criminalisation of modern slavery is a sufficient response to severe labour exploitation. Severe labour exploitation is a grave wrong that causes serious harm to others, and the machinery of criminal law can be a tool that communicates that such conduct is unacceptable. However, the meagre provision of civil remedies for victims of modern slavery in the MSA does not send an equally strong message that these victims should be supported for the grave wrong

\footnotetext{
3 Home Office, 'Historic Law to End Modern Slavery Passed' (26 March 2015) at https://www.gov.uk/government/news/historic-law-to-end-modern-slavery-passed.

${ }^{4}$ Theresa May, 'My Government will lead the way in Defeating Modern Slavery' (The Telegraph, 31 July 2016) at https://www.telegraph.co.uk/news/2016/07/30/we-will-lead-the-way-in-defeatingmodern-slavery/.

5 National Audit Office, 'Reducing Modern Slavery' (15 December 2017) at https://www.nao.org.uk/report/reducing-modern-slavery/ - hereinafter cited as 'National Audit Office Report.'

${ }^{6}$ The MSA received Royal Assent in March 2015.
} 
that they suffered. If the Government's commitment to tackling modern slavery is serious, it has to support the victims and take steps to address the structural factors that create vulnerability to exploitation. The NRM system, the treatment of migrant domestic workers in the MSA, and the Immigration Act 2016, exemplify how the steps taken to remove aspects of workers' vulnerability to exploitation are insufficient. The broader context creates scepticism about how genuine the commitment to tackling modern slavery is.

The final part of the article scrutinises the 'transparency in supply chains' section of the MSA, which opts for self-regulation, as opposed to hard law rules. The fact that the regulatory response to what the MSA presents as a grave moral wrong involves a combination of supposedly harsh penalties when it comes to individual perpetrators, with soft law measures when it comes to businesses, might send a confusing message. Yet a soft law approach may not necessarily be problematic, if it can drive change. Has this section had any positive effects? The article considers this question on the basis of analyses of business responses to the MSA. It suggests that where there is any progress at all, it can be measured in inches rather than miles, and this is not expected to change in the near future, because of significant weaknesses in the design of the relevant section. The article concludes that, despite the passing of the MSA, there is much scope for improvement in tackling labour exploitation, even in its most severe forms.

\section{Modern Slavery and the UK policy agenda, central aim and key components}

The concept of 'modern slavery' is increasingly used in political declarations, legal documents and campaigns of non-governmental organisations. ${ }^{7}$ While powerful rhetorically, modern slavery is not usually clearly defined in these documents. ${ }^{8}$ Drawing on insights from the historical institution of slavery, Paz-Fuchs has argued in this Review that in defining the concept of modern slavery we can employ some legal and moral principles of general application, namely humiliation, ownership of the person, exploitation of vulnerability, and denial of choice; and also some legal doctrines that are specific to the employment relation, namely sub-standard working conditions, restrictions on the ability to exit the employment relation, as well as restrictions on the worker's power to control her or his life away from work. ${ }^{9}$

How did modern slavery get onto the UK policy agenda? A line of cases of the European Court of Human Rights (ECtHR) highlighted the need to address the most severe instances of labour exploitation. This case law examined the legislative framework in legal orders, such as France, Cyprus and the UK, ${ }^{10}$ to assess whether it complied with the prohibition of slavery, servitude, forced and compulsory labour under article 4 of the European Convention on Human Rights (ECHR), and imposed

\footnotetext{
${ }^{7}$ See, for instance, Council of Europe, Parliamentary Assembly, Resolution 1983 (2014), 'Prostitution, Trafficking and Modern Slavery in Europe'; ILO '50 for Freedom Campaign' to end modern slavery, launched in October 2015; Anti-Slavery International, 'What Is Modern Slavery?', at https://www.antislavery.org/slavery-today/modern-slavery/.

${ }^{8}$ For analysis see, for instance, C. Costello, 'Migrants and Forced Labour: A Labour Law Response', in A. Bogg, C. Costello, ACL Davies and J. Prassl (eds), The Autonomy of Labour Law (Oxford: Hart, 2015) 198-199. For criticism of the use of the term by certain NGOs and activists, see J. O'Connell Davidson, "Things" Are Not What They Seem: On Persons, Things, Slaves, and the New Abolitionist Movement' (2016) 69 CLP 227.

${ }^{9}$ A. Paz-Fuchs, 'Badges of Modern Slavery' (2016) 79 MLR 757.

${ }^{10}$ See, for instance, Siliadin v France (2006) 43 EHRR 16, hereinafter cited as Siliadin; Rantsev v Cyprus and Russia (2010) 51 EHRR 1, hereinafter cited as Rantsev; CN v UK (2013) 56 EHRR 24.
} 
a range of positive obligations. ${ }^{11}$ The first, highly influential case, Siliadin v France, recognised an obligation on state authorities to enact legislation criminalising slavery, servitude, forced and compulsory labour. Rantsev v Cyprus and Russia emphasised that legislation is not sufficient: authorities also have to take positive operational measures to protect individuals, ${ }^{12}$ when they know or ought to have known that someone is a victim or at real risk of being a victim of treatment contrary to article 4 . The Convention also imposes an obligation to investigate effectively when there is a suspicion that someone is a victim. ${ }^{13}$ For an investigation to be effective, it has to be independent and to have potential to lead to the identification and punishment of those who are responsible for the crime. Investigation has to be prompt, and the victim or next-of-kin have to be involved in the investigation to better safeguard their interests. ${ }^{14}$ When there is a case of human trafficking, the authorities have to cooperate with the relevant authorities abroad if there is a cross-border element. ${ }^{15}$ Moreover, state authorities have to take preventive measures against violations of the provision. ${ }^{16}$ In the UK, early article 4 case law led to the enactment of section 71 of the UK Coroners and Justice Act 2009, entitled 'slavery, servitude, and forced or compulsory labour'. ${ }^{17}$

In addition, in 2013, the think-tank Centre for Social Justice, founded by Conservative MP Iain Duncan Smith, produced a Report entitled 'It Happens Here: Equipping the UK to Fight Modern Slavery'. The Report presented modern slavery as a crime, analysed it as encompassing human trafficking, slavery, servitude, and forced labour, ${ }^{18}$ and proposed that the UK needed a Modern Slavery Act. The Report was influential during the ensuing parliamentary debates. ${ }^{19}$ Against this background, a Joint Committee was formed to consider the Draft Modern Slavery Bill. In parliamentary debates, the problem of modern slavery was presented as a hidden crime of extreme ill-treatment and humiliation, ${ }^{20}$ from which victims must be saved.

The MSA codified and consolidated existing offences and increased sentences for the most serious offenders. It is an improvement on what preceded it, for simplifying and bringing together the offences in one piece of criminal legislation. The pre-existing offences were included in three separate Acts, ${ }^{21}$ an issue which

\footnotetext{
${ }^{11}$ On positive obligations to criminalise under the ECHR, see A. Ashworth, Positive Obligations in Criminal Law (Oxford: Hart, 2015) 196; F. Tulkens, 'The Paradoxical Relationship between Criminal Law and Human Rights' (2011) 9 Journal of International Criminal Justice 577; V. Mantouvalou, 'Human Rights and Criminal Wrongs', in A. Bogg, J. Collins, M. Freedland, J. Herring (eds), Criminality at Work (Oxford: OUP, 2019) forthcoming.

${ }^{12}$ Rantsev, para 286.

${ }^{13}$ Rantsev, para 288.

${ }^{14} L E$ v Greece, para 68. See further OOO, OOA, MTK, RTF v The Commissioner of Police for the Metropolis [2011] EWHC 1246 (QB).

${ }^{15}$ Rantsev, para 289.

${ }^{16}$ Rantsev, para 285.

${ }^{17}$ On this, see V. Mantouvalou, 'Modern Slavery: The UK Response' (2010) 39 ILJ 425.

${ }^{18}$ Centre for Social Justice, 'It Happens Here: Equipping the United Kingdom to fight modern slavery' (11 March 2013) at https://www.centreforsocialjustice.org.uk/library/happens-equipping-unitedkingdom-fight-modern-slavery, s 1.2.1.

${ }^{19}$ See further C. Morgan, "Modern Slavery": Protecting Victims and Prosecuting Culprits', PhD thesis, University of Bristol, 2017, chapter 4.

${ }^{20}$ Hansard, HC, Public Committee Modern Slavery Bill, $3^{\text {rd }}$ sitting, col 87, 2 September 2014, Karen Bradley MP; Hansard, HC Deb Modern Slavery Bill, Second Reading, vol 584, col 166, 8 July 2014, Theresa May MP.

${ }^{21}$ Sexual Offences Act 2003 ss 57-59; Asylum and Immigration (Treatment of Claimants) Act $2004 \mathrm{~s}$ 4, as amended by Protection of Freedoms Act 2012 ss 109 and 110, and Coroners and Justice Act 2009 s 71 .
} 
caused confusion to those responsible for enforcing the law. The fact that one of the offences (trafficking for non-sexual exploitation) was part of immigration law, rather than criminal law, created further misunderstandings. ${ }^{22}$

The stated purpose of the MSA consisted of facilitating the work of prosecutors and the police with regard to modern slavery, ${ }^{23}$ and increasing the rates of prosecutions, which were viewed as low. ${ }^{24}$ The MSA provided for the confiscation of the assets of those who commit modern slavery crimes,${ }^{25}$ and introduced a series of orders: it gave courts the power to make slavery and trafficking reparation orders against those convicted and against whom a confiscation order is made; ${ }^{26}$ slavery and trafficking prevention orders, if there is a risk that a defendant may commit a slavery or trafficking offence and there is a need to protect individuals from harm; ${ }^{27}$ and slavery and trafficking risk orders, if there is a risk that the defendant will commit an offence. ${ }^{28}$ In addition, the MSA introduced a new institution, the Independent AntiSlavery Commissioner, to be appointed by the Secretary of State, whose mandate is to encourage good practice in the prevention, detection, investigation and prosecution of the offences of the Act, as well as the identification of victims. ${ }^{29}$ In relation to protection of victims, the MSA included a range of provisions, such as a new defence for victims of slavery or trafficking who commit a crime, ${ }^{30}$ certain protections for those victims who act as witnesses in criminal proceedings, ${ }^{31}$ civil legal aid, ${ }^{32}$ and independent child trafficking advocates ${ }^{33}$ It also contained a provision on migrant domestic workers. ${ }^{34}$ Finally, the MSA incorporated a new section on transparency in supply chains. ${ }^{35}$

\section{Offences}

The offences in the MSA appear under two headings: first, slavery, servitude, forced and compulsory labour; second, human trafficking. ${ }^{36}$ Section 1 makes it an offence to hold someone in slavery or servitude, or to require someone to perform forced and compulsory labour. In determining whether the offence has been committed, the MSA provides that regard must be had to all circumstances, including personal circumstances that make someone vulnerable, as well as the type of work that the

\footnotetext{
${ }^{22}$ Centre for Social Justice, 'It Happens Here: Equipping the United Kingdom to fight modern slavery', as above n 18, section 5.7.1.

${ }^{23}$ Hansard, HC 8 July 2014, vol 584, col 171.

${ }^{24}$ For instance, in 2013 there were only 68 convictions: Hansard, HC 8 July 2014, vol 584, col 175.

25 s 7 .

${ }^{26}$ s 8 .

${ }^{27}$ ss $14-15$.

${ }^{28}$ s 23.

${ }^{29}$ Part 4.

${ }^{30} \mathrm{~s} 45$. For analysis and critique of the defence under international law, and under the MSA, see M. Jovanovic, 'The Principle of Non-Punishment of Victims of Trafficking in Human Beings: A Quest for Rationale and Practical Guidance' (2017) 1 Journal of Trafficking and Human Exploitation 41.

${ }^{31} \mathrm{~s} 46$.

32 s 47.

${ }^{33} \mathrm{~s} 48$

${ }^{34} \mathrm{~s} 53$.

${ }^{35}$ For a detailed presentation of the provisions of the MSA at the time of its enactment, see J. Hayes, 'The Modern Slavery Act (2015): A Legislative Commentary' (2016) 37 Statute Law Review 33. See also A. Weatherburn, 'Using an Integrated Human Rights-Based Approach to Address Modern Slavery: The UK Experience’ 2016 European Human Rights Law Review 184.

${ }^{36}$ MSA, ss 1-2.
} 
person is required to do, particularly exploitative work. It states that the person having consented to any of the acts that constitute slavery, servitude, forced or compulsory labour does not preclude the finding that they are victims of the crime.

Section 2 of the MSA contains a human trafficking offence. The provision reads as follows: 'A person commits an offence if the person arranges or facilitates the travel of another person ("V") with a view to V being exploited'. ${ }^{37}$ The consent of a victim of trafficking to the travel is irrelevant. What this probably implies is that there is never genuine consent in these situations. The MSA explains that a person may arrange or facilitate someone's travel by, for instance, recruiting, harbouring, transporting or transferring control over another person. The Act requires intent to exploit. The travel, in turn, may be either across borders or within a country. Section 3 of the Act defines exploitation by saying that a person is exploited if that person is subjected to slavery or servitude, is a victim of sexual exploitation, or is subjected to force, threats or deception, in order to provide services etc. Even though aspects of the definition of human trafficking directly mirror elements of the Council of Europe Anti-Trafficking Convention ${ }^{38}$ and the EU Human Trafficking Directive, ${ }^{39}$ other aspects of it differ somewhat from the approach found in these instruments. ${ }^{40}$ The European instruments distinguish between the 'means' (such as recruitment, transportation and harbouring) and the 'purpose' of exploitation, ${ }^{41}$ which the MSA does not do. This approach may generate problems, for instance, when it comes to requests for mutual legal assistance. ${ }^{42}$ Section 4 of the MSA extends the definition of trafficking to include the commission of offences, such as theft, with the intention of human trafficking. The Act increases the maximum penalty to life sentence. ${ }^{43}$

Even though it was said earlier that the MSA constitutes an improvement in comparison to the pre-existing legislation, failures of ambition can be identified if the offences are compared to the draft produced by the Joint Committee on the Draft Modern Slavery Bill. ${ }^{44}$ The Committee Bill broke down the offences into slavery, exploitation and trafficking, while the MSA does not make exploitation a freestanding offence.

The Act explains that the section on slavery, servitude, forced and compulsory labour has to be construed in accordance with case law of the ECtHR under article 4 of the ECHR. ${ }^{45}$ From this case law, we can derive a number of principles on the interpretation of grave labour exploitation. Siliadin, which involved a migrant domestic worker, has been very influential in subsequent debates. ${ }^{46}$ Looking at the concept of 'slavery' in article 4 , the Court ruled that it ought to be interpreted narrowly, according to the 1926 UN Slavery Convention, which links slavery to

\footnotetext{
${ }^{37}$ MSA, s 2 .

${ }^{38}$ Council of Europe Convention on Action against Trafficking in Human Beings, Council of Europe Treaty Series, No 197, 2005.

${ }^{39}$ Council Directive 2011/36/EU of 5 April 2011 on Preventing and Combatting Trafficking in Human Beings and Protecting its Victims [2011] OJ L101/1.

${ }^{40}$ On the history of the evolution and debates on the current definition of human trafficking in international law, see among others A. Gallagher, The International Law on Human Trafficking (Cambridge: CUP, 2010).

${ }^{41}$ EU Directive, n 39 above, Article 2; Council of Europe Convention, n 38 above, Article 4.

${ }^{42}$ Hayes, n 35 above, p 39.

${ }^{43}$ MSA, s 5(1)(a).

${ }^{44}$ Joint Committee on the Draft Modern Slavery Bill, Draft Modern Slavery Bill - Report, 2013-14, HL Paper 166, HC 1019, pp 5-9.

${ }^{45}$ MSA, s 1(2).

${ }^{46}$ See V. Mantouvalou, 'Servitude and Forced Labour in the $21^{\text {st }}$ Century: The Human Rights of Domestic Workers’ (2006) 35 ILJ 395.
} 
ownership. ${ }^{47}$ Article 1(1) of the Slavery Convention defines slavery as 'the status or condition of a person over whom any or all of the powers attaching to the right of ownership are exercised'. ${ }^{48}$ The concept of 'servitude' is broader, and prohibits 'particularly serious form of denial of freedom'. ${ }^{49}$ It includes an obligation to provide certain services for someone and to live in another person's property along with the impossibility of changing this condition. ${ }^{50}$ On forced and compulsory labour, the Court has observed that the wording of article 4 of the Convention has striking similarities to the International Labour Organisation Convention No 29, on which it relies in interpreting the ECHR. The ECtHR interprets 'forced and compulsory labour' to encompass 'all work or service which is exacted from any person and under the menace of any penalty and for which the said person has not offered himself voluntarily'. ${ }^{51}$ In other words, there are two key elements: first, the fear of a penalty; and second, the contrary will of the person. The Court has also underlined in Chowdury that the main criterion distinguishing servitude from forced and compulsory labour is the feeling of the victims that their condition is permanent and that they cannot change it. ${ }^{52}$

The ECtHR has classified trafficking for both sexual and labour exploitation as a violation of article 4 of the ECHR, even though the term is not explicitly mentioned in the provision. ${ }^{53}$ In the first case on human trafficking for sexual exploitation, Rantsev, the Court emphasised that it falls within the ambit of article $4 .{ }^{54}$ It ruled that human trafficking 'by its very nature and aim of exploitation, is based on the exercise of powers attaching to the right of ownership', ${ }^{55}$ treating people as commodities, often for little or no pay, involving close surveillance, violence, life and work in poor conditions. As trafficking is contrary to human dignity and other fundamental values, the Court found that there is no need to identify whether it should be classified as slavery, servitude, forced and compulsory labour, but it is sufficient to say that it is contrary to article $4 .{ }^{56}$ Chowdury confirmed that labour trafficking is also covered by the provision.

The complexity in defining the crimes contained in the MSA can be illustrated by cases in the English criminal courts. ${ }^{57}$ In Regina $v K(S)$ the defendant had been convicted of arranging the entry of a domestic worker in the UK with the intention of exploiting her. Having worked for over three years, the domestic worker alleged that

\footnotetext{
47 Siliadin, para 122.

${ }^{48}$ Theoretical literature questions whether ownership of the person goes to the heart of the moral wrong of chattel slavery. See O. Patterson, Slavery and Social Death (Cambridge MA: Harvard University Press, 1982) 1-14; Paz-Fuchs, n 9 above.

49 Van Droogenbroeck v Belgium, Commission's report of 9 July 1980, Series B, No 44, p 30, paras 78-80.

${ }^{50}$ Van Droogenbroeck v Belgium, App no 7906/77, Commission decision of 5 July 1979, DR 17, p 59.

${ }^{51}$ Van der Mussele v Belgium (1984) 6 EHRR 163 para 32.

${ }^{52}$ See, for instance, Chowdury and Others v Greece ECtHR 30 March 2017 para 99, hereinafter cited as Chowdury. Noted by V. Stoyanova, 'Sweet Taste with Bitter Roots - Forced Labour and Chowdury v Greece' (2018) European Human Rights Law Review 67.

${ }^{53}$ On sex trafficking, see Rantsev, paras 281-282. On labour trafficking, see Chowdury, as above.

${ }^{54}$ Rantsev, para 282.

${ }^{55}$ Rantsev, para 281.

${ }^{56}$ Rantsev, para 282. For criticism of this move, see Ashworth, n 11 above, p 208; Jean Allain, 'Rantsev $v$ Cyprus and Russia: The European Court of Human Rights and Trafficking as Slavery' (2010) 10 Human Rights Law Review 546.

${ }^{57}$ For a discussion of the concept of exploitation in the criminal law context, see J. Collins, 'Exploitation of Persons and the Limits of the Criminal Law' (2017) CrimLR 169.
} 
she was forced to work 24 hours a day, was hardly fed or paid, and was not allowed to go outside alone or to contact her family in Africa. The defendant was convicted under section 4(1) of the Asylum and Immigration (Treatment of Claimants) Act, which is codified in the MSA, according to which a person commits an offence if she or he arranges or facilitates the travel of someone with the intention to exploit the other person. The definition of exploitation in section 4(4) of the Act referred to article 4 of the ECHR. The Court of Appeal quashed the conviction because it found that the judge did not guide the jury sufficiently on the meaning of exploitation, as defined in Siliadin. It said:

In the modern world exploitation can and does take place, in many different forms. Perhaps the most obvious is that in which one human being is treated by another as an object under his or her control for a sexual purpose. But 'slavery or servitude' and 'forced labour' are not confined to exploitation of that sort. One person may exploit another in many different ways. Sexual exploitation is one, domestic servitude, such as was found in Siliadin's case, another. ${ }^{58}$

The case $R$ v $M K$ examined the statutory defence under section 45 of the MSA. ${ }^{59}$ The appellants were victims of human trafficking, and sought to rely on the defence. The question before the Court of Appeal was whether, when raising the defence, the legal or persuasive burden of proof was on the defendant. The Court ruled that the defendant only bears an evidential burden in support of the ingredients of section 45 , and not a legal burden of proving 'beyond reasonable doubt' that he or she had been victim of human trafficking. The burden then is on the prosecution to prove 'beyond reasonable doubt' that the defendant is not a victim of trafficking. This case indicates challenges in the interpretation of the statutory defence.

\section{Prosecutions}

Has the introduction of the MSA led to a significant increase in the number of identifications of victims and prosecutions? It is important to appreciate that the picture of the crime is unclear, and the National Audit Office Report has criticised the Home Office on the collection of data in relation to modern slavery offences. ${ }^{60} \mathrm{In}$ 2014 the Home Office stated that there were between 10,000 and 13,000 potential victims of modern slavery in the UK. ${ }^{61}$ Between April 2015 and March 2016, the police recorded 884 modern slavery crimes, but as the police only introduced 'modern slavery' as a separate category in crime recording in 2015, it is impossible to compare the data before and after the enactment of the MSA. ${ }^{62}$ Yet the year when 884 modern slavery crimes were recorded, there were 3,146 NRM referrals, which suggests a significant mismatch. When referrals are not recorded as slavery crimes,

\footnotetext{
${ }^{58} R$ v $K(S)$ [2012] 3 WLR 933, para 41.

${ }^{59} R$ v $M K$ [2018] EWCA Crim 667 (28 March 2018). See also $R$ v Joseph (Verna) [2017] 1 WLR 3153.

${ }^{60}$ National Audit Office Report, n 5 above, para 2.5.

${ }^{61}$ Home Office, 'True Scale of Modern Slavery in UK Revealed as Strategy to Tackle it Published' (1 December 2014).

62 C. Haughey, 'The Modern Slavery Act Review' (31 July 2016) at https://www.gov.uk/government/uploads/system/uploads/attachment_data/file/542047/2016_07_31_H aughey_Review_of_Modern_Slavery_Act__final_1.0.pdf
} 
no investigations follow. ${ }^{63}$ From December 2016, the National Crime Agency is under an obligation to refer all NRM cases to the police, so in 2016-2017 a total of 2,255 modern slavery cases were recorded.

Against this background, existing data indicates that even though there has been a small increase in prosecutions, the numbers are still strikingly low if assessed against NRM referrals, which is a point that the National Audit Office Report emphasised. ${ }^{64}$ In 2016 there were 80 prosecutions under the MSA, rising from 26 prosecutions in $2015 .{ }^{65}$ Even though the number of prosecutions has increased, it is still very low, and there is a striking discrepancy between the number of prosecutions, the number of modern slavery crimes that are recorded, and the number of referrals of victims of human trafficking through the NRM. Failure to implement adequate measures to protect victims from their exploiters and from victimisation at the hands of the state because of their undocumented legal status makes successful prosecutions more difficult.

The MSA increased the maximum custodial sentence up to life in prison, but this sentence has not been used yet. Existing case law has shown some willingness to impose higher penalties. In $R$ v Zielinski ${ }^{66}$ the offender had conspired with his family to trick very poor and desperate Polish nationals to travel to the UK, with the promise of well-paid work. They were instead kept in appalling conditions, and their wages were confiscated. The Court of Appeal increased a sentence of four years for offences under the MSA to seven years, stating that it was unduly lenient. However, the average length of a custodial sentence between 2014-2016 was about four years' imprisonment, and has not changed significantly in recent years. ${ }^{67}$

In October 2017, a police watchdog, Her Majesty's Inspectorate of Constabulary and Fire \& Rescue Services (HMICFRS), produced a report which was highly critical of the police response to modern slavery for a number of reasons, including a lack of understanding of the issue, ineffective investigations, and the frequency with which victims were referred to immigration authorities instead of being provided with support. ${ }^{68}$ When it comes to the identification and prosecution of individual perpetrators of the crime, in other words, the MSA has thus far failed to meet its stated purpose.

\section{The National Referral Mechanism}

The discussion of the identification and protection of victims under the MSA would be incomplete without reference to the main administrative mechanism dealing with modern slavery allegations and identifying victims, the NRM. It is primarily against the number of NRM referrals that we can assess the success in the number of prosecutions under the MSA, as was said above. Understanding the NRM also helps

\footnotetext{
63 Joint Committee of Human Rights (JCHR), 'Business and Human Rights 2017: Promoting Responsibility and Ensuring Accountability’ (4 April 2017) HL paper 153, HC 443, para 197, citing evidence submitted by the Equality and Human Rights Commission. Hereinafter referred to as 'JCHR Report.'

${ }^{64}$ ibid, para $4.8 \mathrm{ff}$.

${ }^{65}$ National Audit Office Report, n 5 above, para 4.8.

${ }^{66} R$ v Zielinski (David) [2017] EWCA Crim 758.

${ }^{67}$ ibid, para 4.11.

${ }^{68}$ HMICFRS, 'Stolen Freedom: The Policing Response to Modern Slavery and Human Trafficking' (October 2017). On this, see further C. Morgan, 'Modern Slave or Illegal Worker? The Haze around Modern Slavery and its Implications' (LSE Politics and Policy Blog, 17 November 2017).
} 
assess the Government's response towards modern slavery more broadly, which is the reason why the NRM system was analysed in the National Audit Office report. ${ }^{69}$

The NRM was formed in 2009 in order to meet the UK's obligations under the Council of Europe Convention on Action against Trafficking in Human Beings. Even though it pre-existed the MSA, its remit was revised in 2015, after the enactment of the MSA, in order to cover all victims of modern slavery in England and Wales.

There is a two-stage referral process for the identification of victims of modern slavery. First responders, including the police, the border force, local authorities and designated NGOs, can refer individuals to the NRM. The case is then considered by Competent Authorities, who are trained professionals. ${ }^{70}$ If a potential victim has a positive first stage decision, meaning that the Competent Authority considers that there are reasonable grounds to believe that they may have been trafficked, the individual is granted a minimum 45-day reflection and recovery period, while the claim is being considered for a final, or conclusive, grounds decision, made on the balance of probabilities. During this interim period, individuals are not removed from the UK and have access to government-funded accommodation and other support.

The NRM system has several shortcomings that reveal the Government's reluctance to address structural factors that create vulnerability to exploitation, and underline the Government's failure to take effective steps to tackle modern slavery. ${ }^{71}$ The need for reform of the NRM was already clear in 2013 and during the drafting of the MSA, as can be seen in the Joint Committee Report of the Draft Modern Slavery Bill. $^{72}$ The delay in making necessary reforms to the system is unjustifiable. Soon after they receive a conclusive grounds decision, for instance, the victims are abandoned: $:^{73}$ those who have been positively identified as victims get two weeks of Government-funded support and accommodation; those with a negative decision, 48 hours. It is not a surprise therefore that there is evidence that some individuals disappear after that period, and are re-trafficked. Having nowhere to go, they return to the traffickers, and then go through the NRM 'again and again'. ${ }^{74}$

Those who are recognised as victims of human trafficking sometimes simultaneously receive a letter informing them that this finding does not mean that they have a right to remain in the UK. This is problematic for numerous reasons, including the failure to recognise that if deported, these individuals are at a significant risk of being re-trafficked because they will be placed in the same conditions as those that led to their trafficking in the first place. ${ }^{75}$ Significantly, the Government does not

\footnotetext{
${ }^{69}$ National Audit Office Report, n 5 above, Part II.

${ }^{70}$ The UK's two Competent Authorities are based at the UK Human Trafficking Centre and the Home Office.

${ }^{71}$ See National Audit Office Report, n 5 above.

72 Joint Committee on the Draft Modern Slavery Bill, above n 44, p 60 ff. See also Home Office, 'Review of the National Referral Mechanism for Victims of Human Trafficking' (November 2014).

${ }^{73}$ See Human Trafficking Foundation Report, 'Day 46 - Is there life after the safe house for survivors of modern slavery?' (October 2016) at

http://www.humantraffickingfoundation.org/sites/default/files/Human\%20Trafficking\%20Foundation $\% 20$ Report\%202016\%20Day\%2046.PDF

${ }^{74}$ Baroness Butler Sloss, who also described this as a 'ridiculous situation', Oral Evidence, Victims of Modern Slavery, HC 803, 11 January 2017, Q127.

${ }^{75}$ See Coalition of NGOs' Report, 'Supporting Adult Survivors of Slavery to Facilitate Recovery and Reintegration and Prevent Re-Exploitation' (March 2017), 7 at http://www.humantraffickingfoundation.org/sites/default/files/Long\%20term\%20survivor\%20support \%20needs\%20March\%2017\%202.pdf. See also M. McClenaghan, 'UK condemned for deporting
} 
collect data on re-trafficked victims. ${ }^{76}$ During the years $2014-2016$, only 384 out of 2,563 conclusively identified victims were granted discretionary leave to remain in the UK. ${ }^{77}$

The Work and Pensions Committee, which conducted an inquiry on 'Victims of Modern Slavery', recommended an automatic right to remain for those who are identified as victims of modern slavery, ${ }^{78}$ but the Government has resisted the proposal. Sarah Newton MP said: 'We must be mindful that introducing a blanket leave policy creates an unfortunate risk of encouraging individuals who are attempting to frustrate legitimate immigration control to make trafficking claims' ${ }^{79}$ This statement does not recognise that traffickers will not act in the victim's interests to secure a residence permit. ${ }^{80}$ Moreover, such a risk may be said to exist in relation to the exercise of other internationally recognised human rights, such as a right to seek asylum, but this does not mean that the right should not be protected for those who are actually recognised as victims of persecution. In any case, it is important to appreciate that victims of severe exploitation will be extremely reluctant to contact the authorities, if they have no guaranteed right to remain in the country after they have been conclusively identified as victims.

Those working in the field of human trafficking have been critical of the NRM system. A positive conclusive grounds decision, which identifies someone as victim of human trafficking, was described as nothing but a 'piece of paper' by Kate Roberts, Head of the Human Trafficking Foundation, ${ }^{81}$ which means nothing to other state agencies. Roberts explained that ' $[w]$ hen victims are trying to access things, like benefits, there is no understanding of what they have been through, why they don't have documents, why their story does not make sense. It can often be re-traumatising for people because they are asked to explain a lot of things that they have already explained to the competent authority. For victims it is quite-I was going to use the word "destroying", which I don't think is overstating the case. People say, "I was believed and now I have nothing. Now I am being left."... [There is] a lot of evidence with very distressing cases of people left destitute while they are giving evidence to the police, for example. ${ }^{82}$ In addition, there is no formal appeal process for the reasonable or conclusive grounds decisions. Individuals can appeal informally or challenge the decision by judicial review. At present, while any reconsideration request or judicial review of a negative decision is ongoing, victims lose access to support. This makes it likely that they disappear before knowing the outcome of the challenge.

survivors of trafficking to Vietnam' (The Guardian, 20 December 2016) at https://www.theguardian.com/global-development/2016/dec/20/uk-condemned-for-deportingsurvivors-of-trafficking-back-to-vietnam.

${ }^{76}$ Letter of Sarah Newton MP to the Work and Pensions Committee, 17 February 2017, at http://www.parliament.uk/documents/commons-committees/work-and-pensions/Letter-from-SarahNewton-MP-to-Chair-re-modern-slavery-session-17-2-2017.pdf

${ }^{77}$ See P. Burland, 'Smoke But No Fire: How Not to Read UK Government Trafficking Statistics' (Open Democracy, 28 April 2017) at https://www.opendemocracy.net/beyondslavery/patrickburland/smoke-but-no-fire-how-not-to-read-uk-government-trafficking-statistics.

${ }^{78}$ Work and Pensions Committee, 'Victims of Modern Slavery - Twelfth Report of Session 2016-17', HC803 (30 April 2017) Conclusions and Recommendations, para 6.

${ }^{79}$ Letter of Sarah Newton MP, n 76 above.

${ }^{80}$ Work and Pensions Committee Report, n 78 above, para 43.

${ }^{81}$ K. Roberts, Oral Evidence, Victims of Modern Slavery, HC 803, 11 January 2017, Q110.

82 ibid. 
The Anti-Slavery Commissioner said about the NRM process that '[v]ictims are looked at in a very clinical way to almost fit law enforcement requirements' and that even if they get discretionary leave and are supporting police, they may not get jobseekers' or housing allowance because they do not meet the residency standards. And he continued: '[i]f you have been locked up in a farm, or locked up in premises being forced into labour or being sexually exploited, you are not going to be able to produce pay slips, or a P45, or whatever. That is the basics of where we are getting this wrong, even to that level. ${ }^{93}$ The MSA provides in section 49 that the Secretary of State must issue guidance to public authorities on victim identification and support, something which has not occurred to date. It is important to highlight that the state has a more robust duty to provide assistance and support to those who are recognised as victims of modern slavery in Northern Ireland and Scotland. ${ }^{84}$ Leaving victims of trafficking in a position of destitution may raise issues under the ECHR, in light of the Limbuela, Tesema and Adam judgment of the House of Lords, ${ }^{85}$ which ruled that leaving asylum seekers with no social support, in destitution, while their asylum application is pending, violates article 3 of the Convention that prohibits inhuman and degrading treatment. Similarly, MSS v Belgium and Greece established that leaving asylum seekers in a state of extreme poverty and unable to meet their basic material needs violates article 3 ECHR. ${ }^{86}$

The Work and Pensions Committee also produced a critical report on the system, focusing on the protection of victims and recommending a series of improvements that could lead to better support, ${ }^{87}$ including an automatic grant of a right to remain in the country for at least one year with the same recourse to social support as asylum seekers. ${ }^{88}$ In this way, the Committee explicitly rejected the Home Office Minister's view that a right to remain would act as a 'pull factor' that would increase immigration. ${ }^{89}$ Despite many recommendations on how the system could improve, the National Audit Office noted that the Home Office has been extremely slow in making any changes to the NRM..$^{90}$

\footnotetext{
${ }^{83}$ K. Hyland, Oral Evidence, Victims of Modern Slavery, HC 803, 11 January 2017, Q130.

${ }^{84}$ See generally Anti-Trafficking Monitoring Group, 'Class Acts? Examining Modern Slavery Legislation Across the UK' (October 2016) at http://www.antislavery.org/wpcontent/uploads/2017/01/atmg_class_acts_report_web_final.pdf. For instance, the Human Trafficking and Exploitation (Human Trafficking and Support for Victims Act (Northern Ireland), says in section 18(8) that those eligible for assistance and support may continue to receive it even if they leave Northern Ireland, and section 18(9) permits support and assistance to be given after a positive, conclusive determination for as long as the Department of Justice considers necessary. There have been some recent Government announcements on this front, but with very little detail. See Sarah Newton MP, 'Modern Slavery Victims to Receive Longer Period of Support' (26 October 2017).

${ }^{85}$ Regina v Secretary of State for the Home Department (Appellant), ex parte Adam (FC) (Respondent); Regina v Secretary of State for the Home Department (Appellant), ex parte Limbuela (FC) (Respondent); Regina v Secretary of State for the Home Department (Appellant), ex parte Tesema (FC) (Respondent) (Conjoined Appeals) [2006] 1 AC 396.

${ }^{86}$ MSS v Belgium and Greece (2011) 53 EHRR 2.

${ }^{87}$ Work and Pensions Committee, n 78 above.

88 ibid, Conclusions and Recommendations, para 6.

${ }^{89}$ ibid, para 5. The Modern Slavery (Victim Support) Bill also calls for a rehabilitation period of at least 12 months for victims of modern slavery - see further https://services.parliament.uk/bills/201719/modernslaveryvictimsupport.html.

${ }^{90}$ National Audit Office Report, n 5 above, para 2.14.
} 


\section{Criminalisation, Civil Remedies, and Labour Exploitation}

The enactment of the MSA brought the UK in line with some of its international obligations under article 4 of the ECHR, the UN Trafficking Protocol, the Council of Europe Anti-Trafficking Convention, and the EU Anti-Trafficking Directive. The MSA is important symbolically because criminal law stigmatises conduct and individuals, and sends a strong message that the activity in question is a serious wrong that must not be committed. ${ }^{91}$ Criminalisation may also be important practically, to the extent that it influences activity by deterring employers and traffickers from engaging in the criminalised conduct. ${ }^{92}$ An adequate criminal law framework may also lead to an increase in the number of prosecutions (even though at the moment both convictions and compensation claims are relatively low, as was said earlier). However, the enactment of new criminal offences is far from sufficient if the Government's purpose is indeed to tackle workers' exploitation. The weaknesses of the MSA, including its implementation, suggest that the UK may still be in breach of its positive obligations under article 4 . In fact, there are reasons to question how genuine the commitment to address severe labour exploitation is.

\section{Immigration}

Responses to human trafficking in international law have frequently been viewed with scepticism for the reason that the motivation underlying them is to control immigration, rather than to address labour exploitation. ${ }^{93}$ Costello has argued that the definition of human trafficking that is found in the Palermo Protocol to the UN Convention against Transnational Organised Crime (2000), ${ }^{94}$ particularly if read together with other relevant instruments, reflects a 'strong immigration-control ethos'. ${ }^{95}$ Anderson and Andrijasevic remind us that the Palermo Protocol is not a human rights instrument. It is a document that promotes co-operation between states to combat organised crime. It is not about the protection of victims or their restitution. ${ }^{96}$

It should be emphasised here that the case law of the ECtHR on article 4 imposes broader positive obligations on the state that are not limited to individual conduct and criminalisation, so there is more to be done in order to bring UK law fully in line with Strasbourg case law and tackle modern slavery effectively. In Rantsev the Court said:

the duty to penalise and prosecute trafficking is only one aspect of Member States' general undertaking to combat trafficking. The extent of the positive obligations arising under Article 4 must be considered within this broader context. ${ }^{97}$

\footnotetext{
${ }^{91}$ AP Simester and WJ Brookbanks, Principles of Criminal Law (Wellington: Thompson Reuters, $4^{\text {th }}$ ed, 2012) 783.

${ }^{92}$ See generally N. Lacey, 'Criminalization as Regulation: The Role of Criminal Law', in C. Parker, C. Scott, N. Lacey and J. Braithwaite (eds), Regulating Law (Oxford: OUP, 2004).

${ }^{93}$ Costello, n 8 above; B. Anderson and R. Andrijasevic, 'Sex, Slaves and Citizens: The Politics of Anti-Trafficking' (2008) 40 Soundings 135.

${ }^{94}$ Protocol to Prevent, Suppress and Punish Trafficking in Persons, Especially Women and Children, 2237 UNTS 319 of 15 November 2000.

${ }^{95}$ Costello, n 8 above, 206.

${ }^{96}$ Anderson and Andrijasevic, n 93 above, 136. See also J. Fudge, 'Modern Slavery and Migrant Domestic Workers - Policy Brief', The Foundation of Law, Justice and Society, 2016.

${ }^{97}$ Rantsev, para 285.
} 
The positive obligations of state authorities in relation to sex trafficking, as explained earlier, include an obligation to criminalise, to prosecute and investigate, to take positive operational measures to protect individuals at risk in order to prevent this from materialising, and to put in place an appropriate legislative and administrative framework. An implication of Rantsev was that a very restrictive visa regime was incompatible with the ECHR, because the conditions of that visa were linked to trafficking and exploitation. ${ }^{98}$ It would therefore be expected that, as part of the drive to combat modern slavery, amendments would be made to particularly restrictive classes of visa, which place workers in a position of vulnerability to exploitation. However, this has not been the case to date.

The position of migrant domestic workers, which became a central political issue during the drafting and passing of the MSA and was tackled in section 53 of the Act, illustrates the lack of political will to address structural factors that create vulnerability to exploitation and provides further support to the view that control of immigration drives the political agenda. It also serves as an example of what is in reality required if the Government is seriously committed to tackling modern slavery.

From 2012 until 2016 (when some limited changes were made as discussed below), the Overseas Domestic Worker (ODW) visa did not permit domestic workers to change employer, contrary to the regime that existed before 2012. Under the 2012 regime, when migrant domestic workers arrived lawfully in the country accompanying an employer, their visa status tied them to this employer. ${ }^{99}$ Their residency status was lawful only for as long as the employer with whom they entered employed them, to a maximum of six months. The six-month period was not renewable. The visa was criticised in scholarship that suggested, on the basis of empirical research, that it traps migrant domestic workers in ingoing cycles of exploitation. ${ }^{100}$

During the passing of the Modern Slavery Bill through Parliament, a number of organisations argued that in order for the MSA to be serious about combating modern slavery, it would have to revisit the ODW visa. Indeed, in this context, Lord Hylton proposed an amendment, which was voted into the Bill by the House of Lords, and which provided a number of legal protections for migrant domestic workers, including a right to change employer and renew their visa for consecutive periods of twelve months. The Amendment was rejected by the House of Commons, which replaced it with a clause that gives domestic workers who have been formally identified as victims of trafficking or servitude a possibility of being granted a sixmonth visa as a domestic worker that allows them to change employers, but without recourse to public funds. ${ }^{101}$ There was also a promise that there would be an independent review of the visa, for which James Ewins QC was commissioned.

In his final report, Ewins recommended that all domestic workers (and not just those who have been recognised as victims of trafficking) be granted a universal, unconditional right to change employer, and a visa for a maximum of 2.5 years. Despite the Government's commitment in Parliament to implement Ewins's

\footnotetext{
${ }^{98}$ Rantsev, para 293.

99 See Immigration $\quad$ Rules, $159 \mathrm{~A}-159 \mathrm{H}, \quad$ available at <http://www.ukba.homeoffice.gov.uk/policyandlaw/immigrationlaw/immigrationrules/part5/>. ${ }^{100}$ V. Mantouvalou, “Am I Free Now?” Overseas Domestic Workers in Slavery' (2015) 42 Journal of Law and Society 329.

${ }^{101}$ MSA, s 53.
} 
recommendations, ${ }^{102}$ this has not occurred to date. With some subsequent changes through the Immigration Act 2016, only migrant domestic workers who are conclusively recognized as victims of human trafficking through the NRM have the right to stay in the UK for up to 2.5 years. This very limited change can be criticised on many grounds. First, a right to change employer with a visa of less than six months for all these workers who have not been identified conclusively as victims of trafficking is clearly ineffective. Domestic labour is a work sector that requires special relationships of trust between the worker and the employer, which it takes time to build. Second, domestic workers will also be reluctant to leave abusive employers if there is no certainty that they will have a right to stay in the UK. Given the difficulties in proving that they have been victims of trafficking and the more general weaknesses of the NRM system, many domestic workers will prefer to stay with unscrupulous employers rather than risk deportation. ${ }^{103}$ Finally, there is nothing for those domestic workers who are exploited by being underpaid, for instance, but who are not victims of grave exploitation. By failing to change the visa regime, the MSA left this group of workers vulnerable to severe labour exploitation.

\section{No general civil remedy}

In addition, even though the MSA includes some provisions on victims' protection, ${ }^{104}$ criminalisation of modern slavery has not been accompanied by the enactment of suitable civil remedies for them, which is another issue that may give rise to questions under article 4 of the ECHR. Access to compensation for victims of modern slavery is crucial, as was recognised by the Government in its Modern Slavery Strategy in 2014. It can empower them economically, support their societal reintegration, minimise their vulnerability to being re-trafficked and provide them with a sense of justice. ${ }^{105}$ The UK has an international obligation to provide effective compensation to victims of trafficking both from the perpetrators and from the state under the Council of Europe Convention on Action Against Trafficking in Human Beings, ${ }^{106}$ and under the EU Trafficking Directive, which requires that victims of human trafficking have access to schemes of compensation that exist for other victims of violent crime. ${ }^{107}$ The ILO Forced Labour Protocol (2014) also requires that 'all victims of forced or compulsory labour, irrespective of their presence or legal status in the national territory, have access to appropriate and effective remedies, such as compensation', ${ }^{108}$ an issue that is further mentioned in the Forced Labour (Supplementary Measures) Recommendation No 203 (2014). ${ }^{109}$

However, during the passage of the MSA, the Government rejected as unnecessary a proposal to introduce a general civil remedy, stating that the existing civil remedies in tort would be sufficient for victims of modern slavery. It was argued

\footnotetext{
102 Hansard, HC, 17 March 2015, col 650.

${ }^{103}$ See further, Kalayaan, 'Overseas Domestic Workers Left in the Dark by the Immigration Act 2016', (28 June 2016) at http://www.kalayaan.org.uk/news/overseas-domestic-workers-left-in-thedark-by-the-immigration-act-2016-2/

${ }^{104}$ See particularly ss 45-48.

${ }^{105}$ A. Barrenechea, 'Access to Compensation for Victims of Human Trafficking' (Focus on Labour Exploitation Working Paper, July 2016).

106 article 15.

107 article 17.

108 article 4(1).

109 article 12.
} 
that torts, such as intimidation, harassment, assault and false imprisonment, could constitute grounds for compensation, making a general civil remedy under the MSA redundant. ${ }^{110}$

It is puzzling that the Government recognised the grave moral wrong of severe labour exploitation by introducing a crime, but rejected proposals to introduce a general civil remedy that would mirror the gravity of the particular crime in the area of victims' compensation, and opted to refer to remedies available for other wrongs, that do not fit the same circumstances as modern slavery. In Siliadin, France argued that even though slavery was not criminalised at the time, there were two other offences in the French Criminal Code that addressed the relevant wrong (obtaining from someone performance of services without pay, and subjecting someone to working or living conditions incompatible with human dignity by taking advantage of his or her vulnerability). The ECtHR found that these provisions did not provide effective penalties. It noted that 'the increasingly high standard being required in the area of the protection of human rights and fundamental liberties correspondingly and inevitably requires greater firmness in assessing breaches of the fundamental values of democratic societies'. ${ }^{111}$ Even though the question considered by the Court involved criminal offences, there is no reason to think that the principle of effectiveness in the protection of human rights should not apply in connection to the availability of civil remedies for victims of violations. It can, therefore, fairly be argued that by analogy that civil remedies must also reflect the gravity of the wrong that was suffered by the individual.

Although there is no general civil remedy under the MSA, section 8 provides that the court can compensate victims by making a slavery and trafficking reparation order, if the perpetrator is convicted and a confiscation order is made against him or her. The Court must consider making this reparation order even if the prosecution has not requested it, and must also give reasons if it decides not to make such an order. Yet these remedies were said to be of limited significance in the UK Supreme Court case of Taiwo and Onu. ${ }^{112}$ The case involved two migrant domestic workers who arrived in the UK lawfully, under a migrant domestic worker visa. They were both seriously exploited and abused by their employers, who also confiscated their passports. They brought several claims in employment tribunals, for issues such as their minimum wage and dismissal, with the Employment Appeal Tribunal describing the treatment of Ms Taiwo as 'systematic and callous exploitation'. ${ }^{113}$ The issue that reached the Supreme Court involved their claims of race discrimination, with the question being whether discrimination because of immigration status amounts to discrimination on the grounds of nationality. As Baroness Hale explained, under the law of contract or tort these workers have no remedies for the humiliation, fear and distress that they have suffered, but they could have a remedy if their treatment were to breach the Equality Act 2010.

Baroness Hale recognized that the mistreatment of migrant domestic workers is wrong, and discussed what remedies may be available to the victims on the basis of their contract of employment, other employment rights or tort law. Turning to the MSA, Baroness Hale stated:

\footnotetext{
${ }^{110}$ Lord Bates, HL Deb, 23 February 2015, Col 1464.

${ }^{111}$ Siliadin, para 148.

${ }^{112}$ Taiwo v Olaigbe and Onu v Akwiwu [2016] 1 WLR 2653.

113 ibid, para 4.
} 
[The mistreatment] may even amount to the offence of slavery or servitude or forced or compulsory labour under section 1 of the Modern Slavery Act 2015 or of human trafficking under section 2 of that Act. If a person is convicted of such an offence and a confiscation order made against him, the court may also make a slavery and trafficking reparation order under section 8 of the MSA, requiring him to pay compensation to the victim for any harm resulting from the offence. But such orders can only be made after a conviction and confiscation order; and remedies under the law of contract or tort do not provide compensation for the humiliation, fear and severe distress which such mistreatment can cause.

In concluding that the appeals must fail, Baroness Hale emphasised that this was not because Ms Taiwo and Ms Onu did not deserve a remedy, but because the law as it stands does not address all the wrongs that these workers suffered. She then continued by pointing towards the shortcomings of remedies under section 8 of the MSA, urging Parliament to reconsider the issue:

Parliament may well wish to address its mind to whether the remedy provided by section 8 of the Modern Slavery Act 2015 is too restrictive in its scope and whether an employment tribunal should have jurisdiction to grant some recompense for the ill-treatment meted out to workers such as these, along with the other remedies which it does have power to grant. ${ }^{114}$

While there may be certain other avenues for victims of modern slavery to obtain compensation, these are not sufficient. ${ }^{115}$ For instance, workers can go to the employment tribunals with claims of discrimination or non-payment of the minimum wage. However, the Deduction from Wages (Limitation) Regulations $2014{ }^{116}$ prevent anyone from claiming more than two years' unpaid wages. In this way, people who have been exploited for over two years cannot recover their unpaid wages in full. Moreover, if the victims are undocumented workers, they may be unable to claim compensation for contractual claims, because their contract will be viewed as illegal. ${ }^{117}$ The criminalisation of modern slavery in the MSA was not accompanied by suitable redress for the victims of modern slavery, which is a problem that has been observed in other areas of labour regulation where there has been a criminal law response. ${ }^{118}$

\section{Workers' rights}

It has been proposed that a labour law approach is particularly effective when dealing with severe labour exploitation. ${ }^{119}$ Costello has argued that the Protocol to ILO

\footnotetext{
114 ibid, para 34.

115 See further $\mathrm{n} 89$.

116 SI 2014/3322.

${ }^{117}$ Hounga v Allen [2014] 1 WLR 2889. On this, see A. Bogg and S. Greene, 'Rights Are Not Just for the Virtuous: What Hounga Means for the Illegality Defence in the Discrimination Torts' (2015) 44 ILJ 101. See also Patel v Mirza [2016] AC 467. See further S. Greene and A. Bogg (eds), Illegality After Patel v Mirza (Oxford: Hart 2018).

118 A.C.L. Davies, 'Migrant Workers in Agriculture', in C. Costello and M. Freedland (eds), Migrants at Work (Oxford: OUP 2014) 93.

${ }^{119}$ Costello, n 8 above. On sex trafficking in particular, see I. Thiemann, 'Beyond Victimhood and Beyond Employment? Exploring Avenues to Empower Women Trafficked into the Sex Industry'
} 
Convention 29 on Forced Labour, which includes an obligation to prevent forced labour, to strengthen the enforcement of labour law to all workers in all sectors, and to strengthen labour inspections, is appropriate in this context. ${ }^{120}$ Indeed, for the commitment to tackle workers' exploitation to be genuine, criminal legislation focusing on individual perpetrators must be accompanied by robust protection and enforcement of workers' rights, including suitable civil remedies that will empower those whose rights are violated. In parliamentary debates on the MSA, Paul Blomfield MP expressed this concern powerfully:

[T] he Home Secretary deserves credit for pushing the issue of modern-day slavery to the front of the political agenda, but political decisions taken elsewhere in Government will determine whether she is successful. However well meaning her intentions, the good work in the Bill risks being undermined by the Government's consistent attack on employee rights and protections. It is disingenuous of the Government to say that they are combating modern slavery with one hand while the other hand is actively promoting the conditions under which that slavery can take root [...] The prevention of modern-day slavery means ensuring that the cracks in our labour protection framework that permit widespread abuse against global workers are closed. ${ }^{121}$

The MSA and other recent legislation do not indicate willingness to strengthen workers' rights or address structural injustices that lead to exploitation. Quite to the contrary: new legislation creates further vulnerability, underlining the role of the law in the construction of structures of exploitation. ${ }^{122}$ The Immigration Act 2016, for instance, which includes measures that target migrant workers by criminalising illegal working, ${ }^{123}$ shows that concerns of immigration control trump concerns of labour exploitation. ${ }^{124}$ The offence of illegal working applies when someone subject to immigration control works, when that person knows or has reasonable reason to believe that he or she is not entitled to work because of his or her immigration status. This offence also opens the door for confiscation of any wages paid to undocumented workers under the Proceeds of Crime Act 2002. Instead of measures that target migrant workers, a broader legal and regulatory framework is required that will not focus exclusively on criminalisation of the worst forms of labour exploitation, but which will protect workers' rights and develop a variety of regulatory responses to their violations. By way of an example, an increased role for the Gangmasters and Labour Abuse Authority (GLAA) would be a positive step. This authority, formerly known as Gangmasters Licensing Authority (GLA), was set up in 2004, in order to regulate certain sectors of the labour market through a licensing scheme. ${ }^{125}$ The scheme covered agriculture, shellfish and food processing industries, but there have

(2018) ILJ at https://academic.oup.com/ilj/advance-articleabstract/doi/10.1093/indlaw/dwy015/5051932 (last accessed 16 July 2018).

${ }^{120}$ Costello, $\mathrm{n} 8$ above, 220.

${ }^{121}$ Hansard, HC 8 July 2014, vol 584, col 210.

${ }^{122}$ V. Mantouvalou, 'Legal Construction of Structures of Exploitation', in H. Collins, G. Lester and V. Mantouvalou (eds), Philosophical Foundations of Labour Law (Oxford: OUP, 2018) forthcoming. The piece discusses several legal structures that create vulnerability to exploitation, including prison labour and work in immigration detention.

${ }^{123}$ Immigration Act 2016, s 34.

${ }^{124}$ See A.C.L. Davies, 'The Immigration Act 2016' (2016) 45 ILJ 431; K. Bales, 'Immigration Raids, Employment Collusion, and the Immigration Act 2016' (2017) 46 ILJ 279.

${ }^{125}$ See Gangmasters (Licensing) Act 2004. For discussion of the GLA, see Davies, above n 118. 
been suggestions that more sectors should be covered. ${ }^{126}$ The Director of Labour Market Enforcement recently recommended a trial of the scheme in the hand car wash and nail bars sectors. ${ }^{127}$

The criminalisation of severe labour exploitation, to conclude this section, has to be accompanied by further measures to protect workers' rights and support victims of violations, instead of setting up structures that create further vulnerability to exploitation. Without such protective measures we have to question just how genuine the Government's commitment to tackle modern slavery is.

\section{Business and Human Rights}

There is another grave problem, not directly linked to the above, which the MSA opted to tackle, and to which this section now turns. This involves the working conditions in supply chains. The treatment of workers by businesses, either the parent company or others further down their supply chain, is of growing concern. ${ }^{128}$ Several tragic incidents have been reported in the media, ${ }^{129}$ and the ILO has also taken steps to tackle the problem. ${ }^{130}$ The Draft Modern Slavery Bill (2014) did not contain an obligation for businesses to report on modern slavery in their supply chains, with the Government suggesting that such a requirement would be too burdensome for them. ${ }^{131}$ However, the Joint Committee on the Draft Modern Slavery Bill called on the UK to take a lead in eradicating modern slavery in supply chains, relying inter alia on statements by business leaders who suggested that legislation was needed in order to level the playing field for businesses. ${ }^{132}$ In October 2014, the Government, finally, issued a statement that big businesses would have to produce a yearly statement on the measures that they take to keep their supply chains free from modern slavery. ${ }^{133}$

The regulation of business conduct, particularly when there are violations of workers' rights further down the supply chain, is complex. In English law, for instance, the doctrine of separate corporate personality means that there is a 'corporate veil' that creates a significant hurdle in the effort to hold the parent

\footnotetext{
126 JCHR Report, above n 64, para 129.

${ }^{127}$ Director of Labour Market Enforcement, Sir David Metcalf, UK Labour Market Enforcement Strategy 2018/19 (HM Government, May 2018) p 100.

${ }^{128}$ On the role of transnational labour regulation in the context of globalisation, see B. Hepple, Labour Laws and Global Trade (Oxford: Hart, 2005); see also D. Baumann-Pauly and J. Nolan (eds), Business and Human Rights - From Principles to Practice (Abingdon, Oxon; New York: Routledge, 2016).

${ }^{129}$ See, for instance, A. Chakrabortty, 'Your new iPhone's features include oppression, inequality and vast profit' (The Guardian, 19 September 2016) at https://www.theguardian.com/commentisfree/2016/sep/19/your-new-iphone-features-oppressioninequality-vast-profit. See also J. Chan, ‘A Suicide Survivor: The Life of a Chinese Worker' (2013) 28 New Technology, Work and Employment 84.

${ }^{130}$ See ILO Report IV, 'Decent Work in Global Supply Chains', $105^{\text {th }}$ Session of the International Labour Conference (8 April 2016).

131 R. Mason, 'Companies not asked to report slavery in supply chains under new laws' (The Guardian, $\quad 10$ June 2014) at https://www.theguardian.com/globaldevelopment/2014/jun/10/companies-slavery-forced-labour-supply-chains-new-laws.

132 Joint Committee on Draft Modern Slavery Bill, Report on Draft Modern Slavery Bill (3 April 2014) HL Paper 166, HC 1019, Chapter 5. See particularly para 172.

${ }^{133}$ Karen Bradley MP, 'Big Business to be held to account to keep supply chains slavery free' (13 October 2014) at https://www.gov.uk/government/news/big-business-to-be-held-to-account-to-keepsupply-chains-slavery-free.
} 
company accountable. ${ }^{134}$ English courts have examined this issue. In Chandler v Cape plc, ${ }^{135}$ Chandler contracted asbestosis while employed by the subsidiary of Cape plc, and argued that Cape plc was liable on the basis of the common law concept of assumption of responsibility. The Court ruled that the parent company owed a direct duty of care to those employed by its subsidiary in the particular circumstances of that case. Following Chandler, parent companies might be held accountable in the context of corporate groups' activities, though the conditions required for this type of liability mean that it will be rare. ${ }^{136}$

In contrast to the criminalisation of modern slavery found in the early sections of the MSA, when it comes to business conduct we find a soft law provision. The MSA did not attempt to pierce the corporate veil with hard legal rules and sanctions for non-compliant businesses. Instead, it included section 54, entitled 'Transparency in Supply Chains etc', which imposes a duty on businesses to have transparency in their supply chains with respect to slavery and human trafficking. That the MSA takes a soft law approach to the regulation of business conduct is not necessarily problematic at a theoretical level. As Collins has observed in relation to the difference between hard and soft law:

In scholarly examinations of regulatory techniques, a contrast is frequently drawn between 'command and control' styles of regulation and 'responsive' (or reflexive) regulation. The former style of regulation approximates to criminal law. The rules are imposed by the regulator (or parliament): inspectors monitor compliance; and courts or specialist tribunals impose deterrent sanctions against breach of regulations. In contrast, responsive regulation seeks to achieve the collaboration and co-operation of those subject to regulation. In setting the standards, it favours the use of self-regulation, so that within a broad requirement fixed by legislation the participants can settle through negotiation the detailed rules to govern transactions. ${ }^{137}$

Command and control mechanisms are not always the most suitable ones in all areas of wrongdoing, for they may be unsophisticated, the Government may not have the necessary knowledge to identify and address problems, and because the relevant actors may be unwilling to comply. ${ }^{138}$ In labour law in particular, we find examples where the law gives rule-making powers to autonomous processes, by allowing, say, trade unions and employers to decide on exceptions to labour standards. ${ }^{139}$ However, there are also drawbacks to self-regulation, which are discussed below.

Section 54 requires corporate entities carrying on any part of their business in the UK that supply goods or services and have a minimum turnover of $£ 36$ million to produce a 'slavery and human trafficking statement' each year. ${ }^{140}$ The statement has to refer to the steps (if any) taken to ensure that there is no slavery, servitude, forced and compulsory labour or human trafficking in the business or its supply chains. The

\footnotetext{
${ }^{134}$ Adams v Cape Industries Plc [1990] Ch 433.

${ }^{135}$ Chandler v Cape plc [2012] 1 WLR 3111.

${ }^{136}$ A case where Chandler was not followed due to different facts is Thompson v The Renwick Group plc [2014] EWCA Civ 635.

${ }^{137}$ H. Collins, Regulating Contracts (Oxford: OUP, 1999) 65.

${ }^{138}$ J. Black, 'Decentring Regulation: Understanding the Role of Regulation and Self Regulation in a “Post-Regulatory” World' (2001) 54 CLP 103, 106.

${ }^{139}$ C. Barnard and S. Deakin, 'Market Access and Regulatory Competition', in C. Barnard and J. Scott (eds), The Law of the Single Market: Unpacking the Premises (Oxford: Hart, 2002) 219-220.

${ }^{140}$ MSA, s 54(2).
} 
statement may cover issues such as the structure of the organisation, its business and supply chains, its policies and due diligence processes on slavery and trafficking, the parts of the business where there is a special risk, as well as the steps taken to address the risk, and the effectiveness in ensuring that modern slavery does not occur in its business or supply chains, measured against appropriate indicators. It has to be published on the company's website, if it has one. The MSA does not provide for the imposition of any penalties for non-disclosure, except that the Secretary of State can apply for an injunction to compel the company to comply. The Government has produced a guide on the operation of the provision, according to section 54(9). The guide further explains which businesses are covered, and what steps they need to take in order to comply. ${ }^{141}$

This approach to dealing with businesses through self-regulation is common at the international level. ${ }^{142}$ There are several different forms of private compliance programmes, such as codes of conduct, sometimes monitored through internal audits, the type and effectiveness of which vary greatly. ${ }^{143}$ The California Transparency in Supply Chains Act 2010 is similar to the MSA: it requires companies to disclose their efforts to keep supply chains free from slavery and human trafficking. ${ }^{144}$ The obligation applies to corporations doing business in California with annual receipts over $\$ 100$ million, which are required to post reports online setting out: how the company assesses risks of slavery and trafficking in supply chains; whether and how suppliers are audited to ensure compliance; and whether staff are trained on spotting and mitigating risks of slavery and trafficking. Failure to comply results in an action being brought for injunctive relief by the AttorneyGeneral of California. In relation to the effectiveness of the disclosure obligation under the California Act, it has been said that some corporations interpret the MSA as simply requiring a disclosure. In order to comply, they responded by stating that they had taken no measures at all. ${ }^{145}$

Despite the similarities to methods used elsewhere, there are shortcomings both in the design of the system under section 54 and its implementation. ${ }^{146}$ At a general level, it is questionable whether self-regulation alone is the best way to deal with business misconduct. The role of reflexive law in labour law has been questioned in scholarship, especially where workers' human rights are in issue. ${ }^{147}$

141 'Transparency in Supply Chains Etc. - A Practical Guide' (29 October 2015) at https://www.gov.uk/government/uploads/system/uploads/attachment_data/file/471996/Transparency_i n_Supply_Chains_etc A practical_guide final_pdf

${ }^{142}$ See, for instance, the UN Guiding Principles on Business and Human Rights 2011 - Document HR/PUB/11/04 (hereinafter referred to as 'UN Guiding Principles').

${ }^{143}$ For criticism of audits see G. LeBaron and J. Lister, 'Ethical Audits and the Supply Chains of Global Corporations', Sheffield Political Economy Research Institute (2016) Global Political Economy Brief No. 1, 1.

144 Senate Bill 657, Full text available at https://oag.ca.gov/sites/all/files/agweb/pdfs/cybersafety/sb_657_bill_ch556.pdf .

${ }^{145}$ S. Eckert, 'The Business Transparency on Trafficking and Slavery Act: Fighting Forced Labor in Complex Global Supply Chains' (2013) 12 Journal of International Business and Law 383, 396.

${ }^{146}$ For theoretical analysis of the section, and discussion of its potential and shortcomings, see S. Wen, 'The Cogs and Wheels of Reflexive Law - Business Disclosure under the Modern Slavery Act' (2016) 43 Journal of Law and Society 327.

147 The approach has been questioned on the basis of empirical evidence in other areas of labour regulation. See C. Barnard, S. Deakin, R. Hobbs, 'Reflexive Law, Corporate Social Responsibility, and the Evolution of Labour Standards: The Case of Working Time', ESRC Centre for Business Research, University of Cambridge, Working Paper No 294. For a more general account of reflexive law and labour law, see D. Ashiagbor, 'Evaluating the Reflexive Turn in Labour Law', in A. Bogg, C. Costello, ACL Davies and J. Prassl (eds), The Autonomy of Labour Law (Oxford: Hart, 2015). 
Particularly in relation to the regulation of business conduct, self-regulation has been criticised for simply protecting businesses from reputational damage and for limiting their liability, and has been shown through empirical research to be ineffective unless combined with strong public institutions and laws. ${ }^{148}$

Moreover, the international and national efforts to regulate business conduct that infringes human rights do not only focus on issues of slavery, servitude, forced and compulsory labour or human trafficking. As business conduct may, and does, interfere with all human rights protected in international treaties, the business and human rights agenda involves the full range of internationally recognised human rights, such as freedom of expression, freedom of association and the prohibition of discrimination. ${ }^{149}$ The narrow focus of the MSA on the worst forms of labour exploitation creates the impression that this is the only matter where business conduct should be regulated. Even for this grave form of labour exploitation, the regulation is very minimal and non-interventionist, so one wonders what this means for other human rights abuses by businesses, such as the violation of trade union rights. When it comes to labour rights, it has rightly been pointed that the transparency obligation should not be limited to slavery only, but should cover at least the core ILO Conventions, and should also involve trade unions that can ensure the veracity of the section 54 statement. ${ }^{150}$

When it comes to the detail of the MSA provision, its design is such that it cannot be effective, which was also criticised in the National Audit Office Report. ${ }^{151}$ The section's shortcomings include: the fact that there is no central list of businesses with an annual turnover of over $£ 36$ million which have to comply with the legislation; the lack of a mechanism that monitors whether businesses that are covered by the Act produce a statement; and the fact that there is no official central repository for the statements of businesses, which can only be found on their websites. This makes the statements difficult to access. There are two private initiatives, through the Business and Human Rights Resource Centre and the TISC report, which put the statements together in an online register, in an attempt to make the reports more easily available. ${ }^{152}$ In addition, as noted above non-compliance with the obligation to report does not carry any sanctions except the possibility that an injunction is applied for, and the statement that businesses have to produce under section 54 can merely say that they have done nothing, ${ }^{153}$ in a similar manner to the California Act. Moreover, there is no provision to enable access to remedies for victims of modern slavery by businesses under the MSA, ${ }^{154}$ an issue that was also raised by the Joint Committee of Human Rights in its Report on 'Human Rights and Business 2017'. ${ }^{155}$ Furthermore, even though it seems that the MSA has received

\footnotetext{
148 See R.M. Locke, The Promise and Limits of Private Power: Promoting Labor Standards in a Global Economy (Cambridge: CUP, 2013). See also K. Macdonald, The Politics of Global Supply Chains (Cambridge: Polity, 2014) 71.

${ }^{149}$ UN Guiding Principles, above n 142, principle 12.

150 JCHR Report, above n 64, para 102, statement by Keith Ewing.

151 ibid, para 1.13-1.14.

${ }^{152}$ The respective registers are available at https://business-humanrights.org/en/uk-modern-slavery-actregistry and https://tiscreport.org.

${ }_{153} \mathrm{MSA}, \mathrm{s}$ 54(4)(b).

${ }^{154}$ See R. McCorquodale, 'Survey of the Provision in the United Kingdom of Access to Remedies for Victims of Human Rights Harms Involving Business Enterprises', (BIICL, July 2015) at https://www.biicl.org/documents/724 uk access to remedies.pdf?showdocument=1.

155 JCHR Report, above n 64, para $181 \mathrm{ff}$.
} 
relatively broad media coverage and attention, ${ }^{156}$ there is still a problem of awareness. It has been pointed out that about a third of the businesses whose directors are members of the Institute of Directors were unaware of the existence of the MSA altogether. ${ }^{157}$

There is some evidence that certain businesses have responded positively to the provision during the first years of the operation of the reporting obligation. During the first year, about 1,700 companies released statements, with some big companies showing engagement with the issue. ${ }^{158}$ The MSA has generated discussions by companies that might not have otherwise considered the problem of severe labour exploitation. ${ }^{159}$ According to analyses of the first statements, ${ }^{160}$ five sectors produce half of the reports: these are professional services firms, (including lawyers and employment agencies), manufacturers, retailers, IT firms and food suppliers. Other sectors, such as construction and real estate, also produce reports. Chemicals and pharmaceuticals are underrepresented, even though they often engage in large-scale global supply chain operations. The engagement of sectors such as services and real estate with the reporting obligation seems to have been triggered by the MSA and is viewed as a positive development, given that traditionally they did not engage with such issues. ${ }^{161}$ The statements of businesses became longer and better between 2016 and 2017 in relation to issues such as their supply chains and modern slavery policies, according to Ergon Associates. Statements of large multinationals are generally more informative than those of other businesses, as they are more exposed to scrutiny by investors and consumers. ${ }^{162}$ The Business and Human Rights Resource Centre analysed 27 company statements produced by FTSE 100 companies under the MSA, ${ }^{163}$ and found that the Act is driving some change, with some companies, such as Marks \& Spencer and SAB Miller, demonstrating rigorous action. ${ }^{164} \mathrm{BT}$ has said that in light of the MSA, it decided to assess its business operations, particularly in the area of recruitment, and Sky has performed a risk assessment in its operations on modern slavery. A key finding was that the companies that are the highest performing provide details of the risks and how these are addressed. ${ }^{165}$

However, analyses of the existing reports also show that many do not meet the

\footnotetext{
156 The year of its enactment, for instance, it was covered at great length in mainstream media, such as the Guardian, the Financial Times, the BBC and The Telegraph.

${ }^{157}$ JCHR Report, above n 64, para 104, quoting Andrew Silvester, Institute of Directors.

${ }^{158}$ P. Bloomer, 'A Year After the UK Modern Slavery Act, Time for a Global Modern Slavery Agreement?' (Thomson Reuters, 31 March 2017) at http://news.trust.org/item/20170331091619akvgh/?utm_content=bufferdb627\&utm_medium $=$ social\&utm_source=twitter.com\&utm_campaign=b uffer

$\frac{\mathrm{u}}{159}$ ibid.

${ }^{160}$ Ergon Associates, 'Reporting on Modern Slavery: The Current State of Disclosure - May 2016' (May 2016) at http://ergonassociates.net/wp-content/uploads/2017/06/Reporting-on-Modern-Slavery2May-2016.pdf?x74739.

161 ibid.

162 Ergon Associates, 'Modern Slavery Statements: One Year On' (April 2017) at http://ergonassociates.net/wp-content/uploads/2016/03/MSA_One_year_on_April_2017.pdf?x74739.

163 The FTSE 100 is an index composed of the 100 largest companies listed on the London Stock Exchange.

${ }^{164}$ Business and Human Rights Resource Centre (BHRRC), 'FTSE 100 at the Starting Line: An Analysis of Company Statements Under the UK Modern Slavery Act' (January 2017) at https://business-

humanrights.org/sites/default/files/documents/FTSE\%20100\%20Modern\%20Slavery\%20Act.pdf 165 ibid.
} 
basic, minimal requirements of the MSA. ${ }^{166}$ Even looking at the FTSE 100 company statements, only 56 per cent comply with these requirements. ${ }^{167}$ Many reports are not signed off by the company director and do not go further than a general indication of the company's processes. Ergon Associates analyses suggest that statements are often identical, which may indicate that the process is a mechanical exercise rather than a substantive engagement with the problem or that reports are put together by external consultants who use the same template for all companies. Often they simply make general statements, rather than providing a detailed explanation of their processes for risk assessments.

Moreover, while supply chain relationships are generally covered in reports, very few of these cover contractor relationships, such as agencies or subcontractors, where many labour rights abuses occur. Some reports specifically state that they only examine their operations in the UK, excluding franchisees or operations overseas, ${ }^{168}$ despite the terms of the MSA covering all activities. From the analysis of the FTSE highest performing companies, most contain very little information on the structure and complexity of their supply chains, and many do not provide specific information on how they measure their effectiveness in dealing with modern slavery, with only two companies stating that they have developed performance indicators. ${ }^{169}$ More generally, even if some of the reports comply with the law technically, they do not really engage with its spirit by identifying risks and taking action to mitigate them. ${ }^{170}$ The majority of the FTSE 100 company reports failed to provide insight on how they attempt to tackle modern slavery, according to the Business and Human Rights Resource Centre assessment. ${ }^{171}$

One of the recommendations of the Joint Committee of Human Rights on section 54 was that the government should support the Private Members' Bill proposed by Baroness Young of Hornsey. ${ }^{172}$ This Bill - The Modern Slavery (Transparency in Supply Chains) Bill ${ }^{173}$ - sought to amend the MSA in a number of areas: it included public bodies in the transparency in supply chains requirements of the Act; required companies and public bodies to publish their modern slavery statements in their company reports with bodies such as Companies House; required the Secretary of State to put together a list of companies that are captured by the MSA's transparency in supply chains provision; and prevented public bodies from procuring services from companies which have not conducted due diligence.

There are several recent initiatives, similar to the MSA, on business conduct in other legal orders. For instance, the EU Non-Financial Reporting Directive requires companies with over 500 employees to report on policies on respect for human rights, as well as environmental and other such issues, ${ }^{174}$ the Dutch

\footnotetext{
${ }^{166}$ Ergon Associates, nn 160 and 162 above; BHRRC, n 163 above.

167 n 164 above.

168 Ergon, n 162 above, 3.

${ }^{169}$ BHRRC, n 164 above.

${ }^{170} \mathrm{~F}$. Churchill, 'Less than $6 \%$ of modern slavery reports compliant with law' (CIPS, 1 September 2016) at https://www.cips.org/en/supply-management/news/2016/september/less-than-6-of-supplychain-transparency-reports-compliant-says-human-rights-group/.

${ }^{171}$ BHRRC, $\mathrm{n} 164$ above, 6.

172 ibid, para $89 \mathrm{ff}$.

173 See https://services.parliament.uk/bills/2016-17/modernslaverytransparencyinsupplychains.html [HL]. This Bill lapsed with the dissolution of Parliament for the election in June 2017.

${ }^{174}$ Council Directive 2014/95/EU of 22 October 2014 amending Directive 2013/34/EU as regards disclosure of non-financial and diversity information by certain large undertakings and groups [2014] OJ L330/1.
} 
Government passed the Child Labour Due Diligence Law, ${ }^{175}$ France adopted a Human Rights Due Vigilance Law, ${ }^{176}$ Switzerland is considering mandatory human rights due diligence and parent company liability legislation, and Australia has opened an inquiry on the need for a Modern Slavery Act. The French law, by way of an example, applies to large companies established in France (about 100 companies in total). It establishes an obligation for businesses to identify and prevent adverse human rights and environmental impacts stemming from their activities, from activities of businesses that they control, and from activities of their subcontractors and suppliers. In the US, the Federal Acquisition Regulation prohibits selling a product sourced overseas through federal contracts, if it is mined, produced or manufactured by forced child labour. ${ }^{177}$

As for examples of due diligence processes that have been used and are discussed in academic literature, ${ }^{178}$ these include grievance mechanisms, such as whistleblowing. Some businesses have indeed set up anonymous hotlines, which serve as a confidential avenue through which employees can express concerns about human rights violations and other such issues. ${ }^{179}$ Human rights impact assessments constitute another example of processes that can help identify and tackle the effects of business conduct on human rights of workers or other individuals. ${ }^{180}$

It has been suggested that the many different initiatives that aim to address business conduct at national and supranational level can be confusing for businesses, and that there should therefore be some co-ordination or an international high standard. ${ }^{181}$ There are indeed some recent international efforts in the field. The UN Human Rights Council has created an Inter-Governmental Working Group on Business and Human Rights. ${ }^{182}$ This Working Group seeks to develop a new international legally binding instrument, which will aim to regulate, through international human rights law, the activities of business. The aim is to impose obligations on states in relation to their actions to protect human rights abuses by companies and to provide enforceable remedies to victims. It may also make companies directly legally responsible for their human rights abuses. ${ }^{183}$ Such international initiatives have the advantage that, if widely ratified, they will set common standards and obligations for developing and developed states, reducing businesses' ability to relocate in order to avoid human rights obligations. However,

175 India Committee for the Netherlands, 'Child Labour Due Diligence Law for Companies Adopted by Dutch Parliament' (8 February 2017) at http://www.indianet.nl/170208e.html.

${ }^{176}$ European Coalition for Corporate Justice, 'French Corporate Duty of Vigilance Law' (February 2017) at https://businesshumanrights.org/sites/default/files/documents/French\%20Corporate\%20Duty\%20of\%20Vigilance\%20 Law\%20FAQ.pdf

${ }^{177}$ Federal Acquisition Regulation, 48 CFR §101, at 22.15.

${ }^{178}$ See R. McCorquodale, L. Smit, S. Neely and R. Brooks, 'Human Rights Due Diligence in Law and Practice: Good Practices and Challenges for Business Enterprises’ (2017) 2 Business and Human Rights Journal 195.

${ }^{179}$ See, for instance, the Speak Up programme of the Anglo American Group at https://www.speak-upsite.com.

${ }^{180}$ See N. Gotzmann, 'Human Rights Impact Assessment of Business Activities: Key Criteria for Establishing a Meaningful Practice' (2017) 2 Business and Human Rights Journal 87.

${ }^{181}$ Bloomer, above n 158.

${ }^{182}$ Human Rights Council, Resolution 26/9 (14 July 2014) 'Elaboration of an International Legally Binding Instrument on transnational corporations and other businesses with respect to human rights' UN Doc A/HRC/RES/26/9.

${ }^{183}$ On this new treaty on Business and Human Rights, see O. De Schutter, 'Towards a New Treaty on Business and Human Rights' (2015) 1 Business and Human Rights Journal 41; D. Bilchitz, 'The Necessity for a Business and Human Rights Treaty’ (2016) 1 Business and Human Rights Journal 203. 
the UK's stance towards this development has been characterised by lack of engagement in any public setting, and they voted against the creation of the treaty process in the UN Human Rights Council. ${ }^{184}$ Given that the UK Government wants to have a world-leading role in the field, it is to be hoped that it will support all efforts and international initiatives in this area.

\section{Conclusion}

Severe labour exploitation is a grave moral wrong, the criminalisation of which should be welcomed: it is important symbolically because criminal law stigmatises conduct and individuals, and sends a strong message that the activity in question is a serious wrong that must not be committed. However, the MSA has not been successful in meeting the key aim of increasing prosecutions, and has not provided adequate civil remedies to victims. In addition, criminal law alone is far from sufficient for the regulation of the employment relation, not least because it focuses on individual conduct rather than structural injustices and relations of domination between employers and workers, both in the global order and at national level. An exclusive focus on criminal law obscures the role of the law as a structure that creates relations of subordination. ${ }^{185}$ Criminalisation of labour exploitation has to be accompanied by effective protection and enforcement of workers' rights and provision of suitable remedies for the wrong that they have suffered. There is little evidence of such effective protection of workers' rights in the MSA or the broader legislative framework. It is also telling that the first Independent Anti-Slavery Commissioner, Kevin Hyland OBE, resigned in May 2018. His resignation letter stated: 'At times independence has felt somewhat discretionary from the Home Office, rather than legally bestowed'. ${ }^{186}$ This appears to reinforce and add to the concerns about the robustness of the current regime that were discussed above.

The MSA also has shortcomings in its approach to the regulation of business conduct, where we find a very weak provision that is supposedly designed to tackle the most extreme abuse of labour rights. Slavery-like practices in supply chains are unlikely to be eliminated through the MSA's approach. Existing analyses of business responses to the MSA requirements indicate that there is still a long way to go, both because the legal requirement is very weak and because there are indications that the statements produced are the product of a mechanical exercise without substantive engagement and detailed information on concrete steps taken to address the problem. At the same time, the light touch approach of the Act might send a confusing message, as it suggests that businesses can get away unscathed, even if they do not take any serious steps to tackle modern slavery.

The commitment to take effective steps to eliminate modern slavery has yet to be met. Labour exploitation cannot be tackled by criminalising employers alone while

\footnotetext{
${ }^{184}$ Human Rights Council, above n 182. For further information on the Human Rights Council session see 'Open-ended intergovernmental working group on transnational corporations and other business enterprises with respect to human rights' at http://www.ohchr.org/EN/HRBodies/HRC/WGTransCorp/Pages/IGWGOnTNC.aspx. 
building structures that create vulnerability to exploitation. It cannot be addressed without empowering workers or while undermining structures that strengthen them. If the Government is serious about its commitment to address labour exploitation, there is still a great deal to be done. 